ARTICLE

\title{
Stretchable chiral pockets for palladium-catalyzed highly chemo- and enantioselective allenylation
}

Yuchen Zhang ${ }^{1}$, Xue Zhang ${ }^{2 凶}$ \& Shengming Ma (1) ${ }^{1,2 \bowtie}$

Pyrazolones are a vital class of heterocycles possessing various biological properties and much attention is paid to the diversified synthesis of enantiopure pyrazolone derivatives. We describe here the development of diphenylphosphinoalkanoic acid based chiral bisphosphine ligands, which are successfully applied to the palladium-catalyzed asymmetric allenylation of racemic pyrazol-5-ones. The reaction affords $\mathrm{C}$-allenylation products, optically active pyrazol5-ones bearing an allene unit, in high chemo- and enantioselectivity, with DACH-ZYC-Phos$\mathbf{C 1}$ as the best ligand. The synthetic potential of the C-allenylation products is demonstrated. Furthermore, the enantioselectivity observed with DACH-ZYC-Phos-C1 is rationalized by density functional theory studies.

\footnotetext{
${ }^{1}$ Laboratory of Molecular Recognition and Synthesis, Department of Chemistry, Zhejiang University, Hangzhou, Zhejiang, P. R. China. ${ }^{2}$ State Key Laboratory of Organometallic Chemistry, Shanghai Institute of Organic Chemistry, Chinese Academy of Sciences, Shanghai, P. R. China. ${ }^{凶}$ email: xzhang@sioc.ac.cn; masm@sioc.ac.cn
} 
yrazolones are a vital class of heterocycles possessing various biological properties ${ }^{1}$. Of particular interest are the pyrazolone derivatives with a chiral center (Fig. 1a): compound $\mathbf{A}$ and its derivatives were proven to be orally active growth hormone secretagogues ${ }^{2,3}$; compound $\mathbf{B}$ was used as a modulator of TRPM8; ${ }^{4}$ compound $\mathbf{C}$ shows remarkable anti-tumor activity related to lung, colon, and breast cancer cell ${ }^{5,6}$. Thus, much attention has been paid to the diversified synthesis of bioactive enantiopure pyrazolone derivatives ${ }^{7-27}$. Along this line, enatioselective allylation of pyrazolones has been established ${ }^{9-12}$. For allene derivatives, enatioseletive spirocyclizations of pyrazolones with 2,3allenyl acetates have been developed by applying chiral phosphine or transmetal/chiral ligand catalysis (Fig. 1b) ${ }^{13,14}$. So far, there is no report on enantioselective 2,3-allenylation of pyrazolones, which is very attractive owing to the unique biological ${ }^{28-30}$ and chemical properties $^{31-37}$ of the allene unit and pyrazolone moiety.

In this work, inspired by conformationally flexible alkyl chain in the Feng's ligands, we develop the enantioselective allenylation of pyrazolones by fine tuning of the Trost ligands, which leads to the development of a class of stretchable chiral pocket (Fig. 1c).

\section{Results and discussion}

Initially, we studied the enantioselective allenylation of pyrazol-5one 2a with benzyl 2-butylbuta-2,3-dienyl carbonate 1a with some typical and commercially available chiral ligands at $30^{\circ} \mathrm{C}$ in $\mathrm{CHCl}_{3}$ (Fig. 2). With $\mathbf{L} \mathbf{1}$ and $\mathbf{L} 8$ as the ligand, there was a serious competing reaction forming $\mathrm{N}$-allenylation product 4aa. Further screening led to the observation that L2-L7 were sluggish for this allenylation. In the reaction with Trost ligand $\mathbf{L} \mathbf{9}$, no product was observed, while Trost ligand $\mathbf{L 1 0}$ afforded the C-allenylation product $(S)$-3aa in $73 \%$ yield and $50 \%$ ee; interestingly, Trost ligand $\mathbf{L 1 1}$ could give (S)-3aa in 84\% yield and 75\% ee. With $\mathbf{L 1 1}$ as the ligand, subsequent investigation on the solvent effect showed that toluene was the best one, affording $85 \%$ yield $(S)$-3aa with $84 \%$ ee (Fig. 2, entries 1-5). After optimizing the temperature and concentration (Fig. 2, entries 6-11), the reaction at 0.02 $\mathrm{M}$ could give (S)-3aa in $92 \%$ yield and $85 \%$ ee, together with a trace amount of 4 aa at $60{ }^{\circ} \mathrm{C}$ (Fig. 2, entry 11).

Obviously, a higher enantioselectivity was desired and the success of conformationally flexible alkyl chain in the Feng's ligands ${ }^{38-41}$ has caught our attention (Fig. 3a). It was reasoned that the rigid aryl linker in the Trost ligands may be replaced with a flexible alkyl linker for a class of stretchable chiral pockets seeking higher enantioselectivity. Thus, the ZYC-Phos ligands were designed and readily synthesized by amidation of diphenylphosphino alkanoic acids, which were prepared by nucleophilic substitution of ethyl chloroalkanoate or chloroacetic acid (Fig. 3b) for further optimization ${ }^{42-45}$.

With the ligands in hand, we conducted the allenylation with DACH-ZYC-Phos-C2. The reaction afforded $(S)-3$ aa in $85 \%$ ee, albeit with a low conversion ( $14 \%$ yield with $67 \%$ recovery of $\mathbf{1 a}$ ) (Table 1, entry 1). Further optiminization was performed: the reactions at $60{ }^{\circ} \mathrm{C}$ and $80^{\circ} \mathrm{C}$ afforded $(S)-3$ aa in 75 and $80 \%$ yields, respectively, with a similar ee together with $4 \%$ of the $N$-allenylation product 4aa (Table 1, entries 2 and 3). Next, we investigated the effect of concentration (Table 1, entries 4-6) and observed that the ee of $(S)$-3aa was improved to $88 \%$ when the concentration of the reaction was $0.02 \mathrm{M}$. The ee value of $(S)$-3aa was similar with 5.0 mol\% of the ligand (Table 1, entry 7). DADPE-ZYC-Phos-C2, DACH-ZYC-Phos-C3, and DACH-ZYC-Phos-C1 (Table 1, entries 8-10) were then screened and DACH-ZYC-Phos-C1 was found to afford (S)-3aa in 79\% yield and $90 \%$ ee as the chiral ligand with $2 \%$ of $\mathrm{N}$-allenylation product 4aa. Solvent screening (Table 1, entries 11-13) led to the conclusion that toluene was the best choice, exclusively affording (S)-3aa in 100\% yield and 95\% ee. Using toluene as solvent, DACH-ZYC-Phos-C2 and C3 were re-tested (Table 1, entries 14 and 15). Thus, the optimal conditions were redefined as follows: allene $\mathbf{1}$, pyrazolone $\mathbf{2}$ (1.2 equiv),

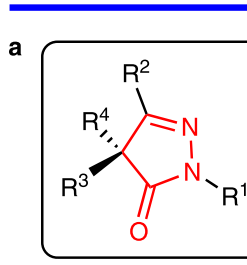<smiles>CN1N=C2CCN(C(=O)[C@H](Cc3ccccc3)NC(=O)C(C)(C)N)C[C@]2(Cc2ccccc2)C1=O</smiles>

A<smiles>CC1=NN(CC(=O)c2ccsc2)C(=O)[C@]1(C)C1CCCCC1</smiles>

B

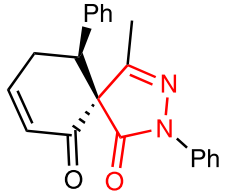

C
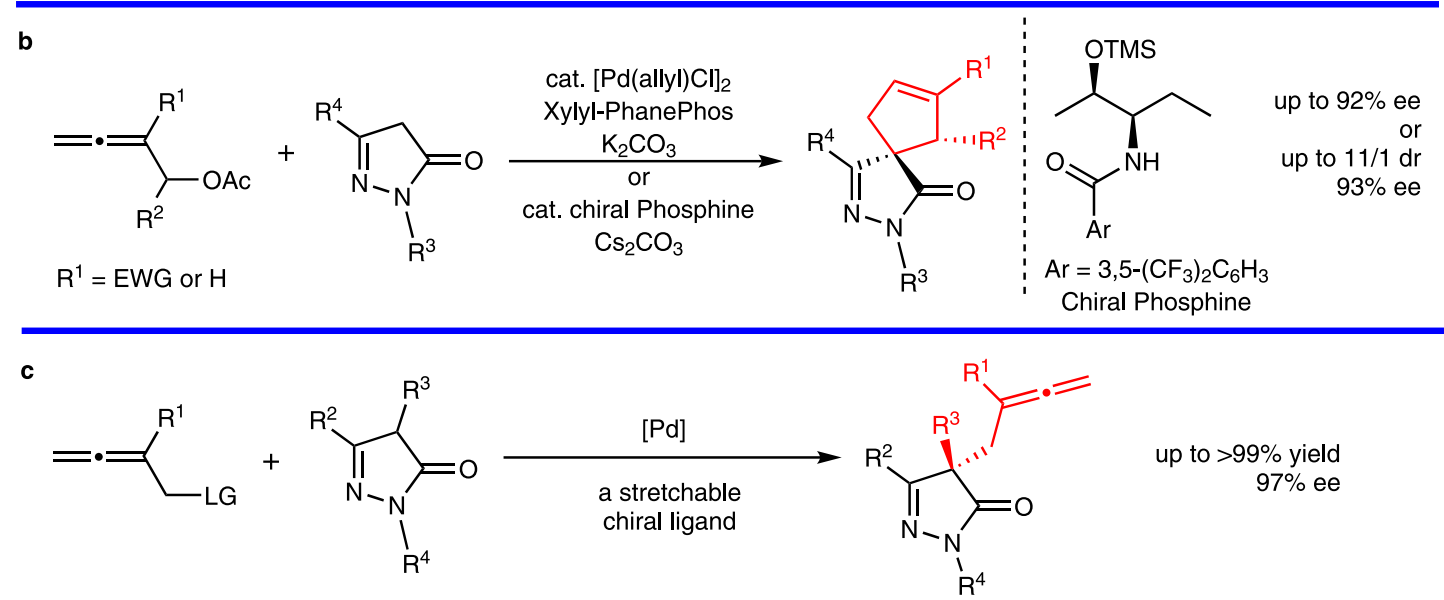

up to $>99 \%$ yield

$97 \%$ ee

Fig. 1 Background and stretchable ligands for asymmetric allenylation of pyrazolones. a Selected examples of biologically active pyrazolones with a chiral center. b Asymmetric spirocyclization of pyrazolones with 2,3-allenyl acetates. c Stretchable chiral pocket for asymmetric allenylation. EWG electron-withdrawing group, TMS trimethylsilyl, LG leaving group. 


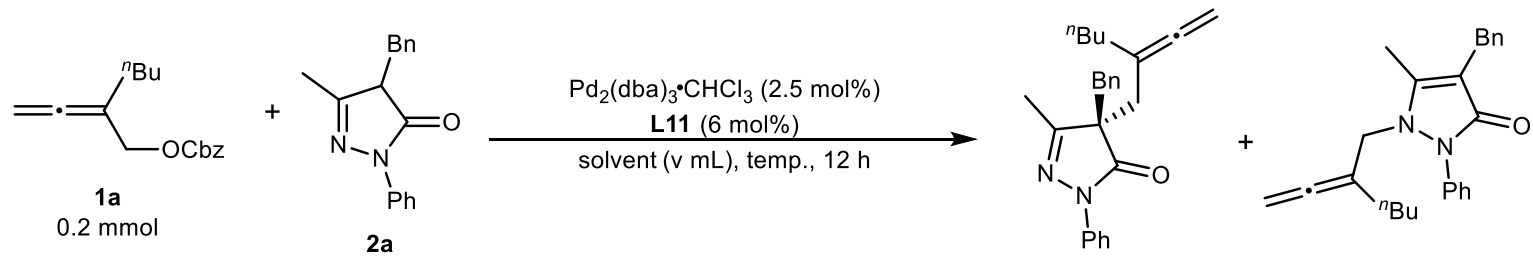

1.2 equiv

(S)-3aa

$4 a a$<smiles>CC(c1ccccc1)N(C(C)c1ccccc1)p1oc2ccc3ccccc3c2c2c(ccc3ccccc32)o1</smiles>

L1

(S)-3aa: $33 \%$ (4\% ee)

4aa: $42 \%$

1a recovered: $0 \%$<smiles>CC1(C)O[C@H](CP)[C@H](CP)O1</smiles>

L5

(S)-3aa: 5\% (n.d.)

4aa: $0 \%$

1a recovered: $85 \%$

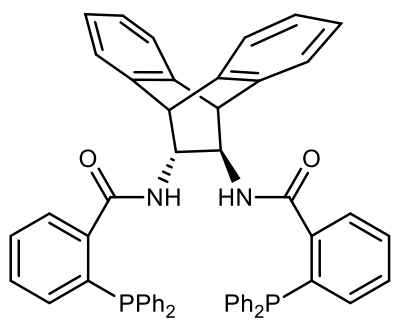

L9

(S)-3aa: $0 \%$ (n.d.)

4aa: $0 \%$

1a recovered: $90 \%$

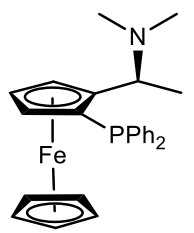

L2

(S)-3aa: 0\% (n.d.) 4aa: $0 \%$ 1a recovered: $85 \%$<smiles>Pc1ccccc1-c1c(-c2ccccc2)ccc2c1OCO2</smiles>

L6

(S)-3aa: $0 \%$ (n.d.) 4aa: $0 \%$ 1a recovered: $91 \%$<smiles>CC(C)CCCCCCc1ccccc1-c1ccccc1</smiles>

L3

(S)-3aa: 0\% (n.d.)

4aa: $0 \%$

1a recovered: $95 \%$<smiles>COc1cccc(P)c1-c1c(P)cccc1OC</smiles>

L7

(S)-3aa: 0\% (n.d.)

4aa: $0 \%$

1a recovered: $93 \%$<smiles>C[C@@H](C[C@@H](C)Pc1ccccc1)Pc1ccccc1</smiles>

L4

(S)-3aa: 0\% (n.d.)

4aa: $0 \%$

1a recovered: $85 \%$

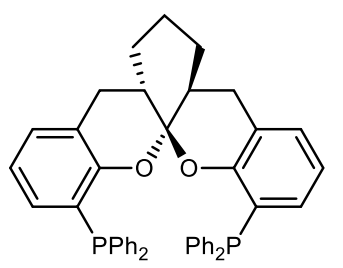

L8

(S)-3aa: 36\% (-11\% ee)

4aa: $32 \%$

1a recovered: $21 \%$<smiles>O=C(N[C@H]1CCCC[C@H]1NC(=O)c1c(-c2ccccc2)ccc2ccccc12)c1cccc2ccccc12</smiles>

L10

(S)-3aa: $73 \%(50 \%$ ee)

4aa: $9 \%$

1a recovered: $13 \%$<smiles>O=C(N[C@H]1CCCC[C@H]1NC(=O)c1ccccc1-c1ccccc1)c1ccccc1</smiles>

$\mathrm{L}^{\mathrm{C}} \mathrm{c}$

(S)-3aa: $84 \%$ (75\% ee)

4aa: $5 \%$

1a recovered: $6 \%$

\begin{tabular}{|c|c|c|c|}
\hline entry $^{a}$ & temp. $\left({ }^{\circ} \mathrm{C}\right)$ & solvent $(\mathrm{mL})$ & yields $(\mathrm{ee})$ of $(S)-3 \mathbf{a a} / \mathbf{4 a a} / \mathbf{1 a}$ recovered $(\%)^{b}$ \\
\hline 1 & 30 & THF (3) & $79(82) / 2 / 18$ \\
\hline 2 & 30 & $\mathrm{CH}_{3} \mathrm{CN}(3)$ & 0 (n.d.)/0/89 \\
\hline 3 & 30 & toluene (3) & $85(84) / 2 / 10$ \\
\hline 4 & 30 & DMF (3) & 0 (n.d.)/0/85 \\
\hline 5 & 30 & $\mathrm{CH}_{3} \mathrm{OH}(3)$ & 0 (n.d.)/0/88 \\
\hline 6 & 40 & toluene (3) & $89(82) / 2 / 5$ \\
\hline 7 & 50 & toluene (3) & $93(79) / 3 / 4$ \\
\hline 8 & 60 & toluene (3) & $94(78) / 2 / 3$ \\
\hline 9 & 30 & toluene (5) & $84(84) / 0 / 14$ \\
\hline 10 & 30 & toluene $(10)$ & $75(86) / 0 / 25$ \\
\hline $11^{d}$ & 60 & toluene (10) & $92(85) / 0 / 0$ \\
\hline
\end{tabular}

Fig. 2 The selected data of optimization with some commercially available chiral ligands. aReaction conditions: 1a (0.2 mmol), 2 a (1.2 equiv), $\mathrm{Pd}_{2}(\mathrm{dba})_{3} \cdot \mathrm{CHCl}_{3}(2.5 \mathrm{~mol} \%)$, and $\mathbf{L 1 - 4}(12 \mathrm{~mol} \%)$ or $\mathbf{L 5}-\mathbf{1 1}$ (6 mol\%) unless otherwise noted. ${ }^{b}$ The yields of (S)-3aa and $\mathbf{4 a a}$ as well as the recovery of $\mathbf{1 a}$ were determined by the ${ }^{1} \mathrm{H}$ NMR analysis of the crude product using mesitylene as the internal standard and the ee of isolated (S)-3aa was determined by chiral HPLC. 'The reaction time was $4 \mathrm{~h}$. ${ }^{\mathrm{d}} \mathbf{L 1 1}$ (5 mol\%) was used and the reaction time was $3 \mathrm{~h}$. Cbz benzyloxycarbonyl, THF tetrahydrofuran, DMF $\mathrm{N}, \mathrm{N}$ dimethylformamide, n.d. not determined. 


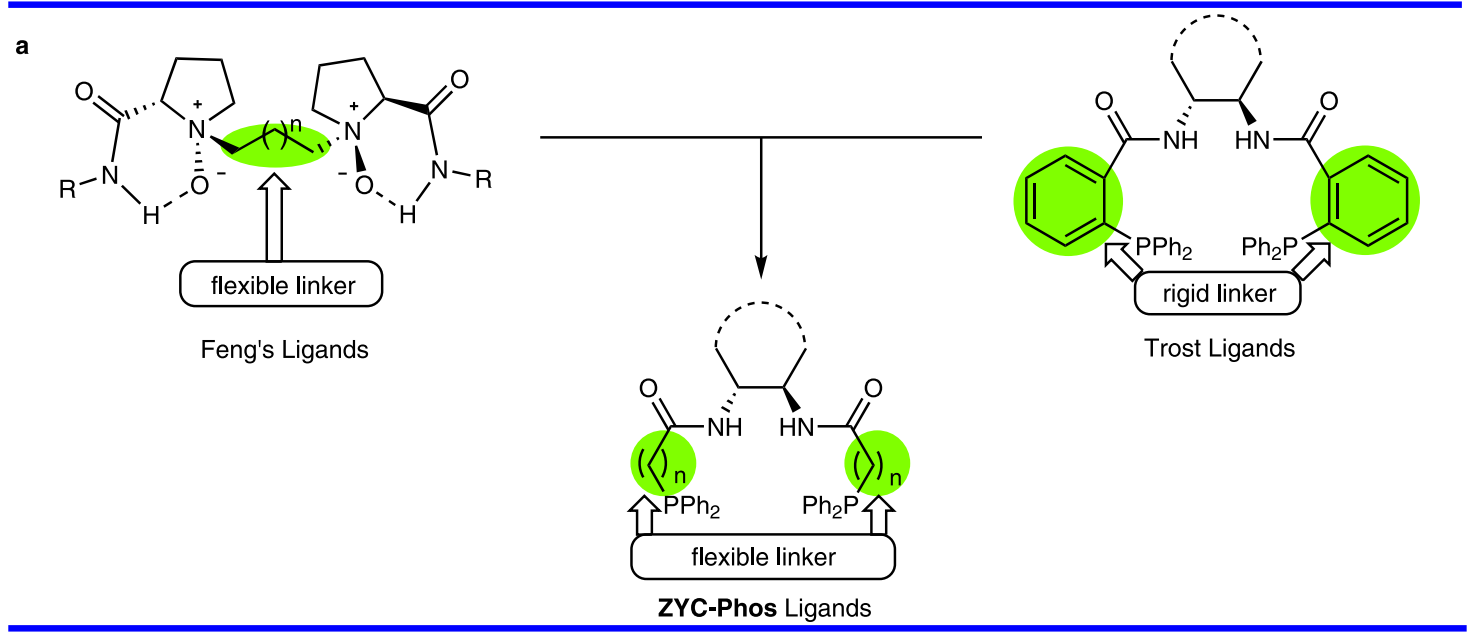

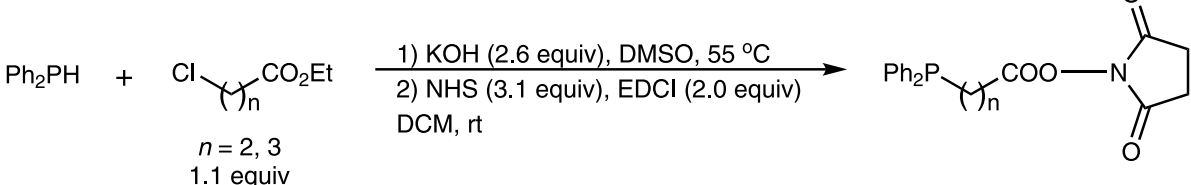

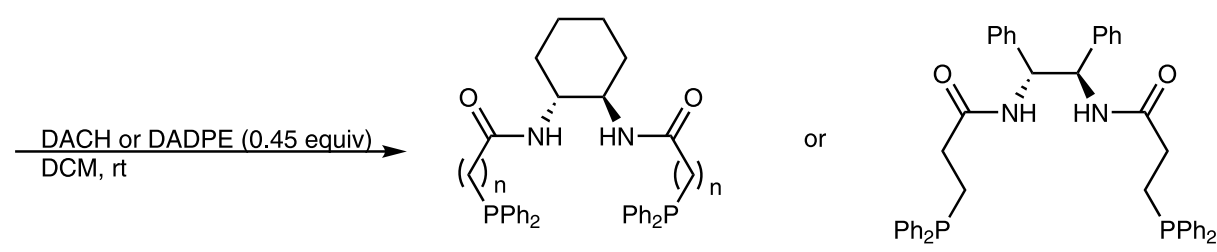

DACH-ZYC-Phos-C2, $\mathrm{n}=2$ DACH-ZYC-Phos-C3, $n=3$

DADPE-ZYC-Phos-C2

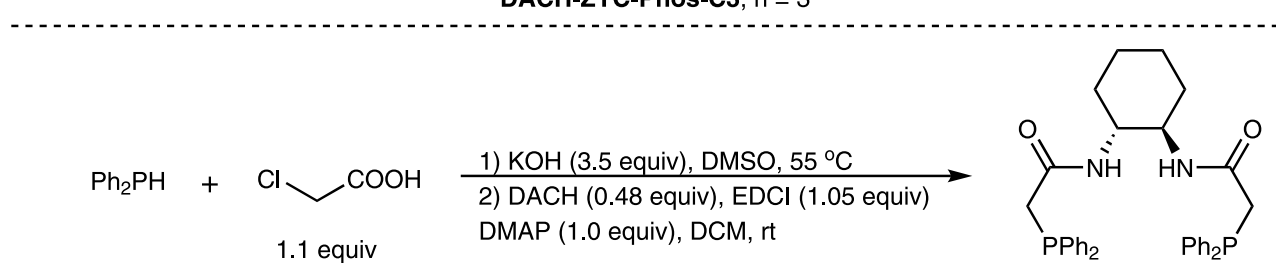

DACH-ZYC-Phos-C1

Fig. 3 Concept and synthesis of the ZYC-Phos ligands. a The concept of ZYC-Phos ligands from the Feng's ligands and the Trost ligands. $\mathbf{b}$ The synthesis of ZYC-Phos ligands. EDCI 1-ethyl-(3-dimethylaminipropyl)carbodiimide hydrochloride, NHS N-hydroxysuccinimde, DMSO dimethyl sulfoxide, DCM dichloromethane, DACH (1R,2 R)-1,2-diaminocyclohexane, DADPE (1R,2 R)-1,2-diphenyl-1,2-diaminoethane, DMAP 4-dimethylaminopyridine.

$\mathrm{Pd}_{2}(\mathrm{dba})_{3} \cdot \mathrm{CHCl}_{3}(2.5 \mathrm{~mol} \%)$, and DACH-ZYC-Phos-Cl $(5.0 \mathrm{~mol}$ $\%)$ in toluene $(0.02 \mathrm{M})$ at $60^{\circ} \mathrm{C}$ (Table 1 , entry 11$)$.

The scope of benzyl buta-2,3-dienyl carbonates 1 was then examined with pyrazol-5-one 2 a. For $\mathrm{R}^{1}, n$-butyl, methyl, $n$-octyl, TMS, and phenyl all worked well with an excellent yield and ee (Table 2, entries $1-5)$. However, when $\mathrm{R}^{1}$ is $\mathrm{H}$, the ee value of $(R)$ 3 fa dropped to $78 \%$ with $86 \%$ yield, indicating a serious steric effect (Table 2, entry 6). The scope of pyrazol-5-ones 2 was then examined with benzyl 2-( $n$-butyl)buta-2,3-dienyl carbonate $\mathbf{1 a}$. The reaction of 4-(ortho-, meta- or para-methylbenzyl)pyrazol-5ones $\mathbf{2 b}$-2d with 1a afforded $(R)$-3ab $\sim(S)$-3ad in similar yields and enantioselectivity (Table 2 , entries 7-9), suggesting that the location of the substituent on the aryl group in the 4-benzyl unit has very limited effect for enantioselectivity. Some synthetic versatile functionalities, such as $\mathrm{Cl}, \mathrm{Br}, \mathrm{F}, \mathrm{CN}, \mathrm{CF}_{3}, \mathrm{MeO}$, and $\mathrm{NO}_{2}$, survived well in the reaction of $\mathbf{1 a}$ and pyrazol-5-ones 2 , affording (S)-3ae $(S)$-3ak in $86-97 \%$ yields and $94-98 \%$ ee (Table 2, entries 10-16). The absolute configuration was determined by the X-ray single crystal diffraction analysis of (S)-3ak
(Fig. 4a). Furthermore, 4-ethyl, 4-allyl, and 4-( $\alpha$-naphthylmethyl) pyrazol-5-ones 2l-2n were exercisable with $87-96 \%$ yields and 93-97\% ee (Table 2, entries 17, 18, 20). As expected, enantiomer (R)-3am was obtained in $95 \%$ yield and $94 \%$ ee by using entDACH-ZYC-Phos-C1 as the ligand (Table 2, entry 19). It should be noted that the difference between the ee values of $(R)-3 \mathbf{a o}$ and $(R)$-3ap suggested that coordination of the hydroxyl oxygen may affect the enantioselectivity (Table 2, entries 21 and 22). Furthermore, for $\mathrm{R}^{3}$ being phenyl, the ee value of $(R)$-3at was only $36 \%$ with $62 \%$ yield (Table 2 , entry 23 ). 3 -Ethyl, 3 -isopropyl, and 3-phenyl pyrazol-5-ones 2q-2s also worked smoothly to offer the products in $91->99 \%$ yields and $95-97 \%$ ee (Table 2, entries 24-26). The reaction of $N$-cyclohexyl pyrazol-5-one $\mathbf{2} \mathbf{u}$ and $\mathbf{1 b}$ afforded $(S)$-3bu in $84 \%$ yield with $95 \%$ ee while the reaction of $N$-benzyl pyrazol-5-one $\mathbf{2} \mathbf{v}$ and $\mathbf{1 b}$ afforded $(S)-\mathbf{3 b v}$ in $82 \%$ yield with $90 \%$ ee (Table 2, entries 27 and 28 ).

The reaction of $1 \mathrm{a}$ and $\mathbf{2} \mathbf{m}$ could be conducted on gram scale facilely, affording $1.20 \mathrm{~g}$ of (S)-3am in a similar yield and enantioselectivity (Fig. 4b-i). Subsequently, an allenic Pauson-Khand 
Table 1 The effect of temperature, concentration, ligands, and solvents on the asymmetric allenylation of pyrazolone $2 a$ with allene 1a.

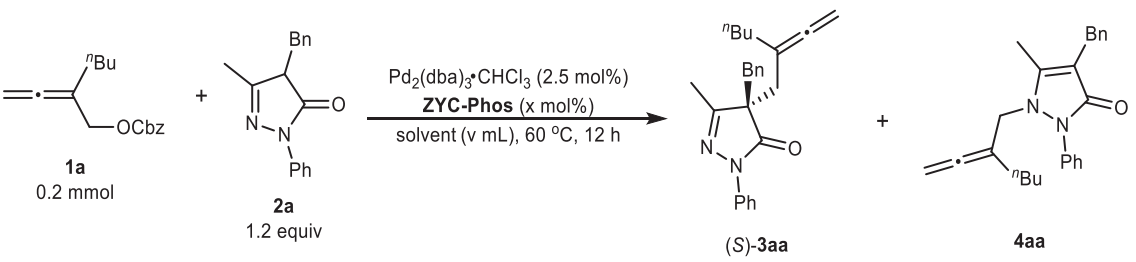

\begin{tabular}{|c|c|c|c|}
\hline Entry & ZYC-Phos & Solvent (v) & Yield (ee) of (S)-3aa/4aa/1a recovered $(\%)^{b}$ \\
\hline$\overline{1^{c}}$ & DACH-ZYC-Phos-C2 & $\mathrm{CHCl}_{3}(3)$ & $14(85) /$ trace/67 \\
\hline 2 & DACH-ZYC-Phos-C2 & $\mathrm{CHCl}_{3}(3)$ & $75(87) / 4 / 6$ \\
\hline $3^{d}$ & DACH-ZYC-Phos-C2 & $\mathrm{CHCl}_{3}(3)$ & $80(86) / 4 / 0$ \\
\hline $4^{e}$ & DACH-ZYC-Phos-C2 & $\mathrm{CHCl}_{3}(1.5)$ & $67(82) / 7 / 4$ \\
\hline $5^{e}$ & DACH-ZYC-Phos-C2 & $\mathrm{CHCl}_{3}(5)$ & $78(87) / 3 / 4$ \\
\hline $6^{f}$ & DACH-ZYC-Phos-C2 & $\mathrm{CHCl}_{3}(10)$ & $70(88) / 2 / 12$ \\
\hline 7 & DACH-ZYC-Phos-C2 & $\mathrm{CHCl}_{3}(10)$ & $76(89) / 2 / 17$ \\
\hline 8 & DADPE-ZYC-Phos-C2 & $\mathrm{CHCl}_{3}(10)$ & $79(79) / 5 / 8$ \\
\hline $9 g$ & DACH-ZYC-Phos-C3 & $\mathrm{CHCl}_{3}(10)$ & $84(76) / 7 / 0$ \\
\hline 10 & DACH-ZYC-Phos-C1 & $\mathrm{CHCl}_{3}(10)$ & $79(90) / 2 / 10$ \\
\hline $11^{\mathrm{h}}$ & DACH-ZYC-Phos-C1 & Toluene (10) & $100(95) / 0 / 0$ \\
\hline 12 & DACH-ZYC-Phos-C1 & THF (10) & $92(83) / 3 / 0$ \\
\hline 13 & DACH-ZYC-Phos-C1 & $\mathrm{CH}_{3} \mathrm{CN}(10)$ & 23 (n.d.)/4/60 \\
\hline 14 & DACH-ZYC-Phos-C2 & Toluene (10) & $87(96) / 0 / 11$ \\
\hline 15 & DACH-ZYC-Phos-C3 & Toluene (10) & $90(87) / 0 / 0$ \\
\hline
\end{tabular}

aReaction conditions: $\mathbf{1 a}(0.2 \mathrm{mmol}), \mathbf{2 a}\left(1.2\right.$ equiv), $\mathrm{Pd}_{2}(\mathrm{dba})_{3} \cdot \mathrm{CHCl}_{3}(2.5 \mathrm{~mol} \%)$, and ligand ( 6 mol\% for entries $1-6 ; 5$ mol\% for entries $\left.7-13\right)$ unless otherwise noted. ${ }^{\text {b The }}$ yields of $(\mathrm{S})$-3aa and $\mathbf{4 a a}$ as well as the recovery of $\mathbf{1 a}$ were determined by the ${ }^{1} \mathrm{H}$ NMR analysis of the crude product using mesitylene as the internal standard and the ee of isolated (S)-3aa was determined by chiral $\mathrm{HPLC}$. ${ }^{\mathrm{C}} \mathrm{At} 30^{\circ}$

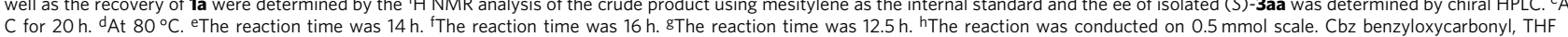
tetrahydrofuran.

annulation of $(S)$-3am was established in $55 \%$ yield and $99 \%$ ee to afford tricyclic product $(3 \mathrm{a} S, 5 \mathrm{~S})-\mathbf{5 a m}$ containing a bicyclic motif with anti-tumor activity 46 (see compound $\mathbf{C}$ in Fig. 1a). The annulation reaction of $(S)$-3da with $o$-(propen-2-yl)phenol could easily construct a seven-membered heterocycle in product $(S, Z)$ 6da (72\% yield, $95 \%$ ee and $>20 / 1 Z / E)^{47}$. The allene unit in $(S)$ 3 da also could be transformed into a 2-propynyl side chain in $(S)$ 7da upon treatment with $\mathrm{TiCl}_{4}$.

A possible mechanism for the allenylation of pyrazolone is shown in Fig. $5 \mathrm{a}^{48-50}$. To better understand the superior enatioselectivity and the advantage of DACH-ZYC-Phos-C1 in the allenylation of pyrazolone, we have conducted X-ray single crystal diffraction studies: firstly, Pd(II)-DACH-ZYC-Phos-C1 complex (III) was prepared by the reaction of $\mathrm{PdCl}_{2}$ and DACH-ZYCPhos-C1 with excess amount of bases in toluene (Fig. 5b). Pd(II)DACH-Phenyl Trost ligand complex (IV) was obtained from the reaction of $\mathrm{Pd}(\mathrm{OAc})_{2}$ with $\mathrm{DACH}$-Phenyl Trost ligand with excess amount of bases in $\mathrm{THF}^{51}$. Both complexes were then recrystalized from $\mathrm{CHCl}_{3} / n$-hexane to afford single crystals suitable for the X-ray diffraction study. It was obvious that the angle (P1-Pd1-P2) and the distance between $\mathrm{P} 1$ and $\mathrm{P} 2$ in III are greater than those in IV $\left(113.21^{\circ}\right.$ vs $102.19^{\circ}, 3.773 \AA$ vs $\left.3.489 \AA\right)$. However, this complex III failed to catalyze the enantioselective allenylation under the standard conditions or with $\mathrm{AcOH}$ as the protic additive (Fig. 5d), indicating that the complex III is not really a catalytically active species but provides a stable coordination mode for the palladium catalysis. The X-ray crystal structures of III and IV were then taken as the starting geometries for all the following calculations involving these complexes by restoring the ligand's amide $\mathrm{N}-\mathrm{H}$.

DFT calculations were performed on the enantioselectivity determining $\mathrm{C}-\mathrm{C}$ bond formation step of the reaction of benzyl buta-2,3-dienyl carbonates $\mathbf{1} \mathbf{b}$ with pyrazol-5-one $\mathbf{2 a}$ catalyzed by the DACH-ZYC-Phos-C1-ligated palladium catalyst (see computational methods in the Supplementary Information for details). The reported energies are Gibbs energies that incorporate the effect of the toluene solvent.

Figure 6 shows the optimized structures and relative free energies of the competing transition states basing on the endomethylene- $\pi$-allyl palladium complexes ${ }^{52}$ (see the Supplementary Information for the other less favorable transition structures with exo-methylene- $\pi$-allyl palladium complexes). These transition structures are denoted as TS_left_Si_a/b, TS_left_Re_a/b, TS_right_Si, and TS_right_Re, separately (left/right indicates that the side of methylene moiety referring to the $\pi$-allyl Pd unit). Among them, TS_left_Si_a with the Si-face attack of $\mathbf{2 a}$ anion, is found to be the most favorable one, which is consistent with the dominant formation of $S$-products observed in the experimental studies.

The ligand's right-side amide $\mathrm{N}-\mathrm{H}$ is available for hydrogen bonding to either the carbonyl oxygen or the hydrazine nitrogen of the approaching 2a anion. The structures of TS_left_Si_a and TS_left_Si_b, leading to the formation of the allenylation product with $S$ configuration, are stabilized by the hydrogen bonding forming between the ligand's $\mathrm{N}-\mathrm{H}$ with the carbonyl oxygen and the hydrazine nitrogen, separately. In the structure of TS_left_Si_a, the H...O distance is $1.81 \AA$, and the bond angle of $\mathrm{N}_{-}^{-}$ $\mathrm{H} \cdots \mathrm{O}$ is $175.0^{\circ}$, which are consistent with the common hydrogen bonding parameters ${ }^{53}$. Based on the electron density at the bond critical point, the hydrogen binding energies (BE) were calculated to analyze the strength of the hydrogen bonding ${ }^{54}$. The bond energy of the hydrogen bonding in TS_left_Si_a was estimated to be about $8.1 \mathrm{kcal} / \mathrm{mol}$. Although the influence of the $\pi / \pi$ interactions between the aromatic rings of the ligand and $\mathrm{N}-\mathrm{Ph}$ 
Table 2 The scope of allenes and pyrazol-5-onesa.

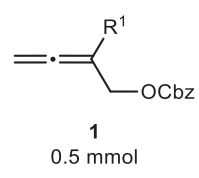

$\mathrm{R}^{1}={ }^{n} \mathrm{Bu}, 1 \mathrm{a} ; \mathrm{Me}, 1 \mathrm{~b}$

${ }^{n} \mathrm{C}_{8} \mathrm{H}_{17}, 1 \mathrm{c} ; \mathrm{TMS}, 1 \mathrm{~d}$

$\mathrm{Ph}, 1 \mathrm{e} ; \mathrm{H}, 1 \mathrm{f}$

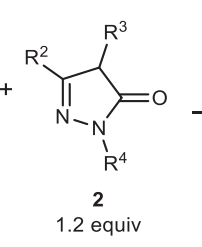

$\mathrm{Pd}_{2}(\mathrm{dba})_{3} \cdot \mathrm{CHCl}_{3}(2.5 \mathrm{~mol} \%)$ DACH-ZYC-Phos-C1 $(5.0 \mathrm{~mol} \%)$ toluene $(0.02 \mathrm{M}), 60^{\circ} \mathrm{C}, 12 \mathrm{~h}$

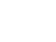

年

\begin{tabular}{|c|c|c|c|}
\hline entry & 1 & $R^{2} / R^{3} / R^{4}(2)$ & yield (ee) of $3(\%)$ \\
\hline 1 & 1a & $\mathrm{Me} / \mathrm{Bn} / \mathrm{Ph}(\mathbf{2 a})$ & $96(95,(S)-\mathbf{3 a a})$ \\
\hline 2 & $\mathbf{1 b}$ & $\mathrm{Me} / \mathrm{Bn} / \mathrm{Ph}(\mathbf{2 a})$ & $91(93,(S)-\mathbf{3 b a})$ \\
\hline 3 & 1c & $\mathrm{Me} / \mathrm{Bn} / \mathrm{Ph}(\mathbf{2 a})$ & $90(93,(S)-\mathbf{3 c a})$ \\
\hline 4 & 1d & $\mathrm{Me} / \mathrm{Bn} / \mathrm{Ph}(\mathbf{2 a})$ & $96(94,(S)-3 d a)$ \\
\hline 5 & 1e & $\mathrm{Me} / \mathrm{Bn} / \mathrm{Ph}(\mathbf{2 a})$ & $>99(97,(S)-3 e a)$ \\
\hline $6^{b}$ & If & $\mathrm{Me} / \mathrm{Bn} / \mathrm{Ph}(\mathbf{2 a})$ & $86(78,(R)-\mathbf{3 f a})$ \\
\hline 7 & 1a & $\mathrm{Me} / \mathrm{o}-\mathrm{MeC}_{6} \mathrm{H}_{5} \mathrm{CH}_{2} / \mathrm{Ph}$ (2b) & $97(95,(R)-\mathbf{3 a b})$ \\
\hline 8 & 1a & $\mathrm{Me} / \mathrm{m}-\mathrm{MeC}_{6} \mathrm{H}_{5} \mathrm{CH}_{2} / \mathrm{Ph}(\mathbf{2 c})$ & $96(92,(S)-3 \mathbf{a c})$ \\
\hline 9 & $1 a$ & $\mathrm{Me} / \mathrm{p}-\mathrm{MeC}_{6} \mathrm{H}_{5} \mathrm{CH}_{2} / \mathrm{Ph}(\mathbf{2 d})$ & $92(95,(S)-3 a d)$ \\
\hline 10 & $1 a$ & $\mathrm{Me} / p-\mathrm{ClC}_{6} \mathrm{H}_{5} \mathrm{CH}_{2} / \mathrm{Ph}(\mathbf{2 e})$ & $97(95,(S)-3 a e)$ \\
\hline 11 & $1 a$ & $\mathrm{Me} / \mathrm{p}-\mathrm{BrC}_{6} \mathrm{H}_{5} \mathrm{CH}_{2} / \mathrm{Ph}(\mathbf{2 f})$ & $96(94,(S)-3 a f)$ \\
\hline 12 & $1 a$ & $\mathrm{Me} / p-\mathrm{FC}_{6} \mathrm{H}_{5} \mathrm{CH}_{2} / \mathrm{Ph}(\mathbf{2 g})$ & $94(94,(S)-3 a g)$ \\
\hline 13 & 1a & $\mathrm{Me} / p-\mathrm{NCC}_{6} \mathrm{H}_{5} \mathrm{CH}_{2} / \mathrm{Ph}$ (2h) & $97(94,(S)-3 a h)$ \\
\hline 14 & 1a & $\mathrm{Me} / p-\mathrm{CF}_{3} \mathrm{C}_{6} \mathrm{H}_{5} \mathrm{CH}_{2} / \mathrm{Ph}$ (2i) & $96(94,(S)-3 a i)$ \\
\hline 15 & 1a & $\mathrm{Me} / \mathrm{m}-\mathrm{MeOC}_{6} \mathrm{H}_{5} \mathrm{CH}_{2} / \mathrm{Ph}(\mathbf{2 j})$ & $95(94,(S)-3 \mathbf{a j})$ \\
\hline 16 & 1a & $\mathrm{Me} / \mathrm{m}-\mathrm{O}_{2} \mathrm{NC}_{6} \mathrm{H}_{5} \mathrm{CH}_{2} / \mathrm{Ph}(\mathbf{2 k})$ & $86(98,(S)-\mathbf{3 a k})$ \\
\hline $17 c$ & 1a & $\mathrm{Me} / \mathrm{Et} / \mathrm{Ph}(\mathbf{2 l})$ & $87(94,(S)-3 a l)$ \\
\hline $18^{d}$ & 1a & Me/allyl/Ph (2m) & $96(93,(S)-3 a m)$ \\
\hline $19^{e}$ & 1a & Me/allyl/Ph (2m) & $95(94,(R)-3 a m)$ \\
\hline 20 & 1a & $\mathrm{Me} / \alpha-$ NaphthylCH $\mathrm{CH}_{2} / \mathrm{Ph}(\mathbf{2 n})$ & $95(97,(R)-3 a n)$ \\
\hline 21 & 1a & $\mathrm{Me} / \mathrm{CH}_{2} \mathrm{CH}_{2} \mathrm{OH} / \mathrm{Ph}$ (2o) & $94(80,(R)-3 a 0)$ \\
\hline 22 & 1a & $\mathrm{Me} / \mathrm{CH}_{2} \mathrm{CH}_{2} \mathrm{OTBS} / \mathrm{Ph}(\mathbf{2 p})$ & $91(93,(R)-3 a p)$ \\
\hline $23^{f, g}$ & 1a & $\mathrm{Me} / \mathrm{Ph} / \mathrm{Ph}(\mathbf{2 t})$ & $62(36,(R)-\mathbf{3 a t})$ \\
\hline 24 & 1a & $\mathrm{Et} / \mathrm{Bn} / \mathrm{Ph}(\mathbf{2 q})$ & $>99(96,(S)-3 a q)$ \\
\hline 25 & 1a & ${ }^{i} \mathrm{Pr} / \mathrm{Bn} / \mathrm{Ph}(\mathbf{2 r})$ & $91(97,(S)-3 a r)$ \\
\hline 26 & 1a & $\mathrm{Ph} / \mathrm{Bn} / \mathrm{Ph}(\mathbf{2 s})$ & $94(95,(S)-3 a s)$ \\
\hline $27^{f}$ & $1 \mathbf{b}$ & $\mathrm{Me} / \mathrm{Bn} / \mathrm{Cy}(\mathbf{2 u})$ & $84(95,(S)-3 \mathbf{b u})$ \\
\hline $28^{f}$ & $\mathbf{1 b}$ & $\mathrm{Me} / \mathrm{Bn} / \mathrm{Bn}(\mathbf{2 v})$ & $82(90,(S)-3 b v)$ \\
\hline
\end{tabular}

aReaction conditions: $\mathbf{1}(0.5 \mathrm{mmol}), \mathbf{2}\left(1.2\right.$ equiv), $\mathrm{Pd}_{2}(\mathrm{dba})_{3} \cdot \mathrm{CHCl}_{3}(2.5 \mathrm{~mol} \%)$, and DACH-ZYC-Phos- $\mathbf{C 1}(5.0 \mathrm{~mol} \%)$ in toluene $(25 \mathrm{~mL})$ at $60^{\circ} \mathrm{C}$ unless otherwise noted. The ee of $\mathbf{3}$ was determined by chiral HPLC. ${ }^{b}$ The reaction time was $2 \mathrm{~h}$. ${ }^{\mathrm{C}} \mathbf{2 l}$ (1.4 equiv) was used and the reaction time was $13 \mathrm{~h}$. ${ }^{\mathrm{d}}$ The reaction time was $11 \mathrm{~h}$. ${ }^{\mathrm{e}}$ ent-DACH-ZYC-Phos-C1 was used and the reaction time was $11 \mathrm{~h}$.

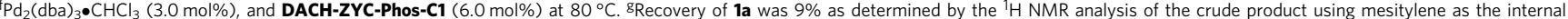
standard. Cbz benzyloxycarbonyl, TMS trimethylsilyl.

pyrazolones on the enantioselectivity could be excluded based on the results of $(S)$-3bu and $(S)-\mathbf{3 b v}$, we have also tried to analyze the non-covalent interactions (NCI) in TS_left_Si_a using the Multiwfn $^{55,56}$ and VMD programs ${ }^{57}$ and no obvious $\pi-\pi$ interactions are found so far from the analysis (see supplementary information for the NCI plot of TS_left_Si_a).

The hydrogen bonding in TS_left_Si_b features a longer H...N distance of $2.18 \AA$ and a smaller $\mathrm{N}-\mathrm{H}$ … $\mathrm{O}$ bond angle of $163.1^{\circ}$, suggesting a weaker interaction, which estimated to be $4.8 \mathrm{kcal} /$ mol. Similarly, hydrogen-bonding interactions also exist in the structure of TS_left_Re_a and TS_left_Re_b, which would provide the allenylation product with $R$ configuration. TS_left_Re_a, is stabilized by the hydrogen bonding formed between the ligand's $\mathrm{N}-\mathrm{H}$ and the carbonyl oxygen of $\mathbf{2 a}$ anion, which was estimated to be about $6.3 \mathrm{kcal} / \mathrm{mol}$. Moreover, TS_left_Re_a suffers the unfavorable interaction between $\mathbf{2 a}$ anion and the methylene- $\pi$-allyl moiety, which have been clearly shown in the Newman projection along the forming $\mathrm{C}-\mathrm{C}$ bond in Fig. 6. Both factors contribute to the lower stability of TS_left_Re_a as compared to TS_left_Si_a by $4.5 \mathrm{kcal} / \mathrm{mol}$. The bond energy of the hydrogen bonding in TS_left_Re_b was estimated to be about $5.4 \mathrm{kcal} / \mathrm{mol}$, which is around $2.7 \mathrm{kcal} / \mathrm{mol}$ weaker than the one in TS_left_Si_a (about $8.1 \mathrm{kcal} / \mathrm{mol}$ ), thus, accounting for the preference of TS_left_Si_a over TS_left_Re_b by $2.3 \mathrm{kcal} / \mathrm{mol}$. Furthermore, TS_right_Si is also stabilized by the hydrogen bonding formed between the ligand's N-H and the carbonyl oxygen of $\mathbf{2 a}$ anion. No corresponding TS is able to be located with hydrogen bonding formed between the ligand's N-H and the hydrazine nitrogen. The bond energy of the hydrogen bonding in TS_right_Si was estimated to be about $5.8 \mathrm{kcal} / \mathrm{mol}$. What's more, the steric repulsions between $2 \mathbf{a}$ anion and the methylene$\pi$-allyl moiety destabilize TS_right_Si. Both factors lead to the less stability of TS_right_Si than TS_left_Si_a by $3.3 \mathrm{kcal} / \mathrm{mol}$. In addition, there is no hydrogen bonding existing in TS_right_Re. And unfavorable steric interactions between the two phenyl groups of 2a anion and the DACH-ZYC-Phos-C1 ligand further destabilize TS_right_Re, making it the least stable transition state $(10.0 \mathrm{kcal} / \mathrm{mol}$ higher in energy than TS_left_Si_a $)$. The calculated enantioselectivity, basing on the energy difference between TS_left_Si_a and TS_left_Re_b of $2.3 \mathrm{kcal} / \mathrm{mol}$, is $94 \%$, which is 


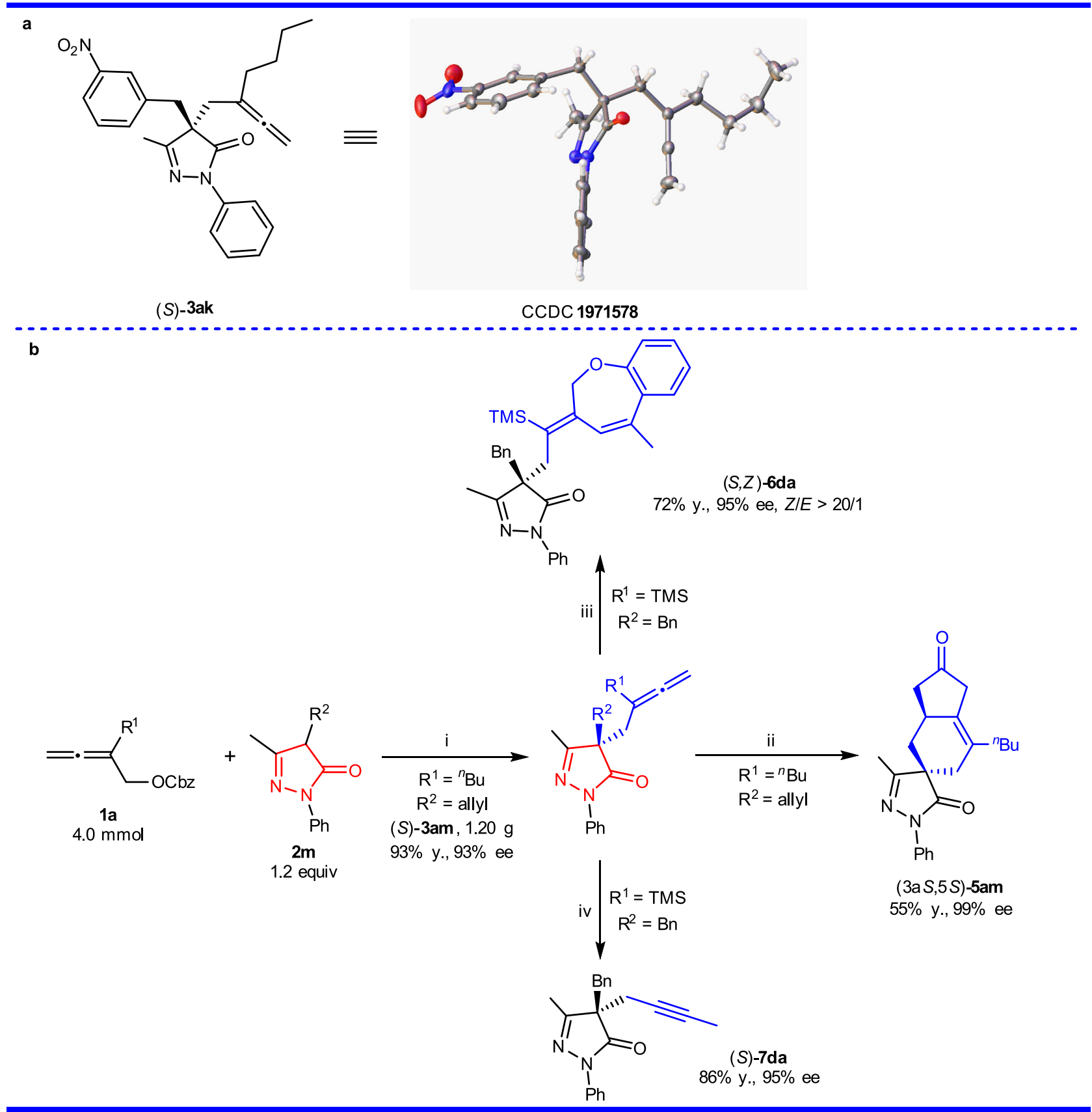

Fig. 4 ORTEP representation and sythetic applications. a ORTEP representation of (S)-3ak. b The gram-scale reaction and applications: reaction conditions: (i) $\mathrm{Pd}_{2}(\mathrm{dba})_{3} \bullet \mathrm{CHCl}_{3}(2.5 \mathrm{~mol} \%)$, DACH-ZYC-Phos-C1 (5.0 mol\%), toluene, $60^{\circ} \mathrm{C}, 13 \mathrm{~h}$; (ii) $\left[\mathrm{Rh}(\mathrm{CO})_{2} \mathrm{Cl}\right]_{2}(5.0 \mathrm{~mol} \%), \mathrm{AgSbF}_{6}(12.5 \mathrm{~mol} \%)$, $\mathrm{CO}$ balloon, toluene, $50^{\circ} \mathrm{C}, 13 \mathrm{~h}$; (iii) ortho-(propen-2-yl)phenol (3.0 equiv), $\mathrm{Pd}(\mathrm{OAc})_{2}(7.5 \mathrm{~mol} \%), 2,2^{\prime}-$ bipy $(7.5 \mathrm{~mol} \%), \mathrm{Cu}(\mathrm{OAc})_{2} \bullet \mathrm{H}_{2} \mathrm{O}(0.5 \mathrm{equiv})$, toluene, $110^{\circ} \mathrm{C}, 18 \mathrm{~h}$; (iv) $\mathrm{TiCl}_{4}$ (1.5 equiv), dichloromethane, $-78^{\circ} \mathrm{C}, 2.5 \mathrm{~h}, \mathrm{rt}, 5.5 \mathrm{~h}$. TMS trimethylsilyl, Cbz benzyloxycarbonyl, y. isolated yield.

in perfect agreement with the experimental ee value of $93 \%$ (Table 2, entry 2).

Similar calculations were then conducted to compare with DACH-Phenyl-Trost ligand. The optimized structures and relative free energies of the competing transition states of the enantioselectivity-determining $\mathrm{C}-\mathrm{C}$ bond formation step, associated with the endo-methylene- $\pi$-allyl palladium complexes, are illustrated in Fig. 7a, which are denoted as TS'_left_Si_a/b, TS'_left_Re_a/b and TS'_right_Si, separately. It should be noted that the structure of TS'_right_Re has not been located successfully, despite all the efforts, probably due to the severe steric repulsions. Different from the DACH-ZYC-Phos-C1 participated reaction, all the transition structures with methylene moiety lying on the left side to the $\pi$-allyl Pd unit suffer the steric interactions causing by $\mathbf{2 a}$ anion with the phenyl group in phenyl-Trost ligand, which reduce their stability. Nevertheless, via avoiding the unfavorable hindrance caused by the nucleophile 2a anion with the phenyl group in phenyl-Trost ligand, TS'_right_Si becomes the most favorable transition state. The energy difference between the diastereomeric TS'_right_Si and TS'_left_Re_b is found to be $1.2 \mathrm{kcal} / \mathrm{mol}$. The calculated enantioselectivity of $71 \%$ in favor of also the $S$ enantiomer is in agreement with the experimental ee value of $71 \%$ (Fig. $7 b$ ).

In summary, we have developed a DPPAA-based ligand for the highly chemo- and enantioselective allenylation of pyrazol-5-ones with benzyl 2,3-dienyl carbonates (up to $97 \%$ ee). Many 


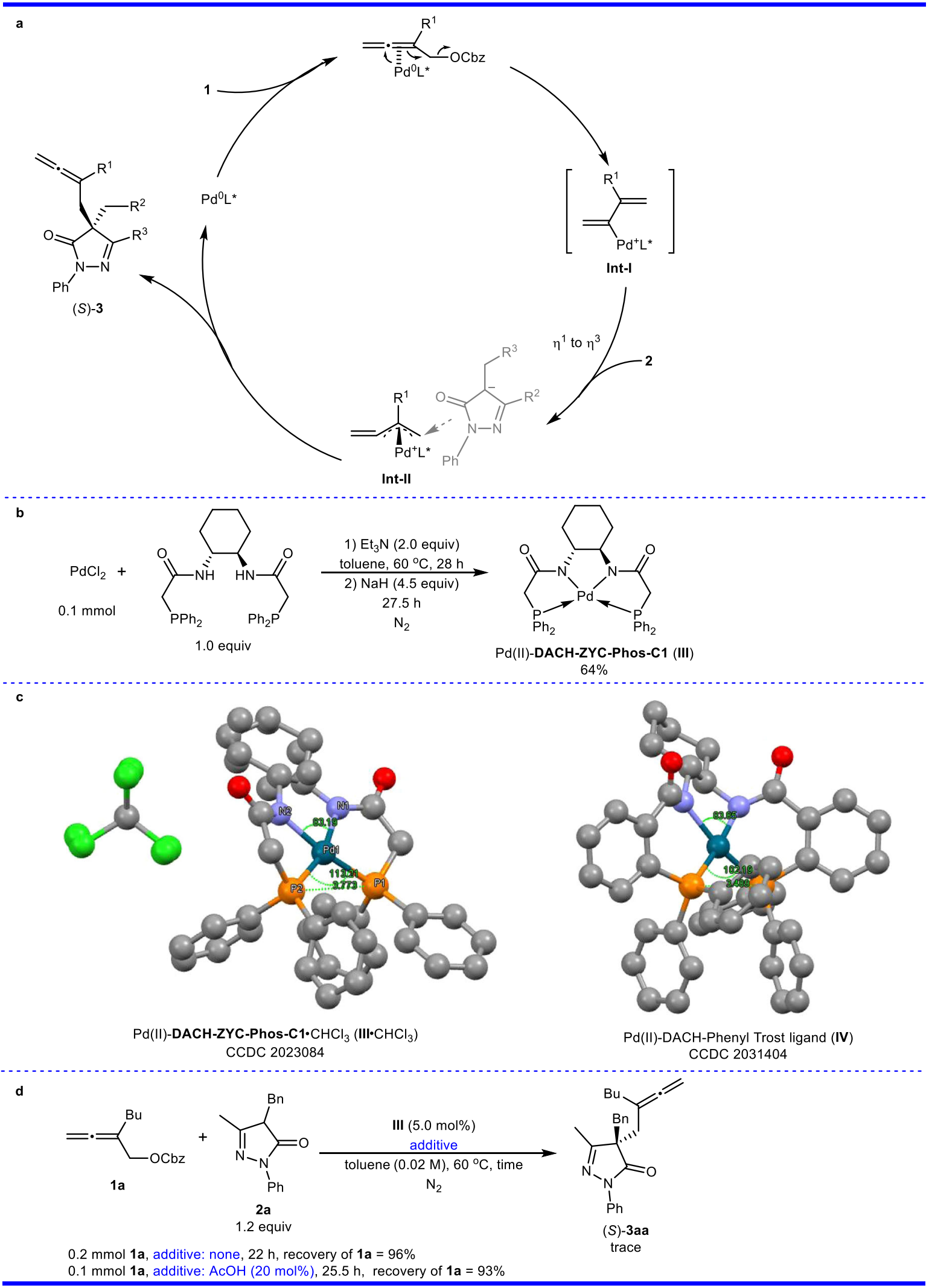

Fig. 5 A proposal mechanism and some experiments for Pd-ligand complexes. a A mechanism for the allenylation of pyrazolone. b Synthesis of Pd(II)DACH-ZYC-Phos-C1 complex III. c ORTEP representations of Pd(II)-ligand complexes III and IV. H-atoms are omitted for clarity. d The reaction of pyrazolone $\mathbf{2 a}$ and allene $\mathbf{1 a}$ with complex III. Cbz benzyloxycarbonyl, DACH (1R,2 R)-1,2-diaminocyclohexane. 


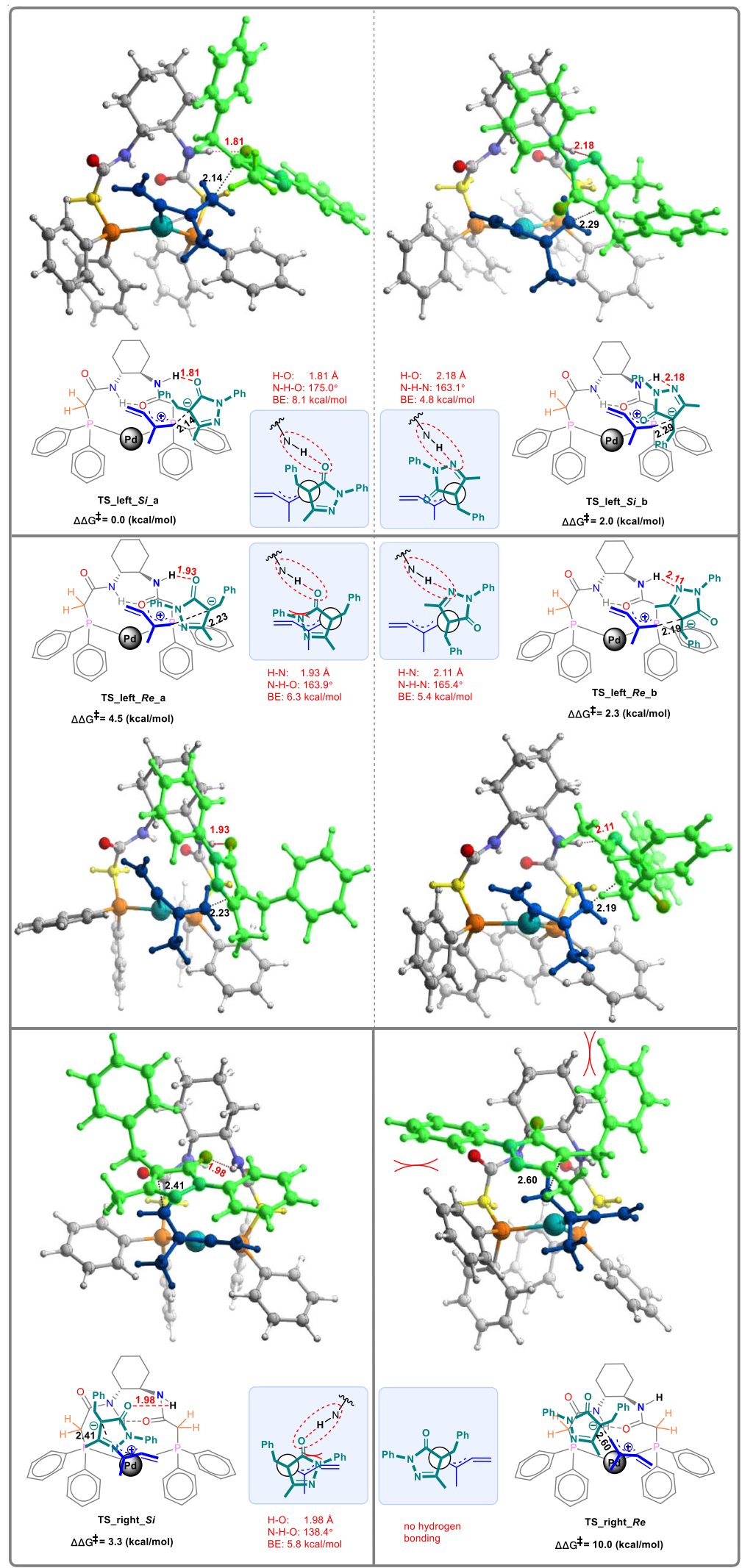

Fig. 6 DFT calculations for DACH-ZYC-Phos-C1-ligated palladium catalyst. DFT-optimized structures and relative energies of stereo-determining C-C bond formation transition states of the reaction of $\mathbf{1 b}$ with $\mathbf{2 a}$ catalyzed by the DACH-ZYC-Phos-C1-ligated palladium catalyst. Hydrogen-bonding interactions are shown as red dash lines; selected bond lengths $(\AA)$ and bond angles $\left(^{\circ}\right)$ are listed. BE bond energy. 


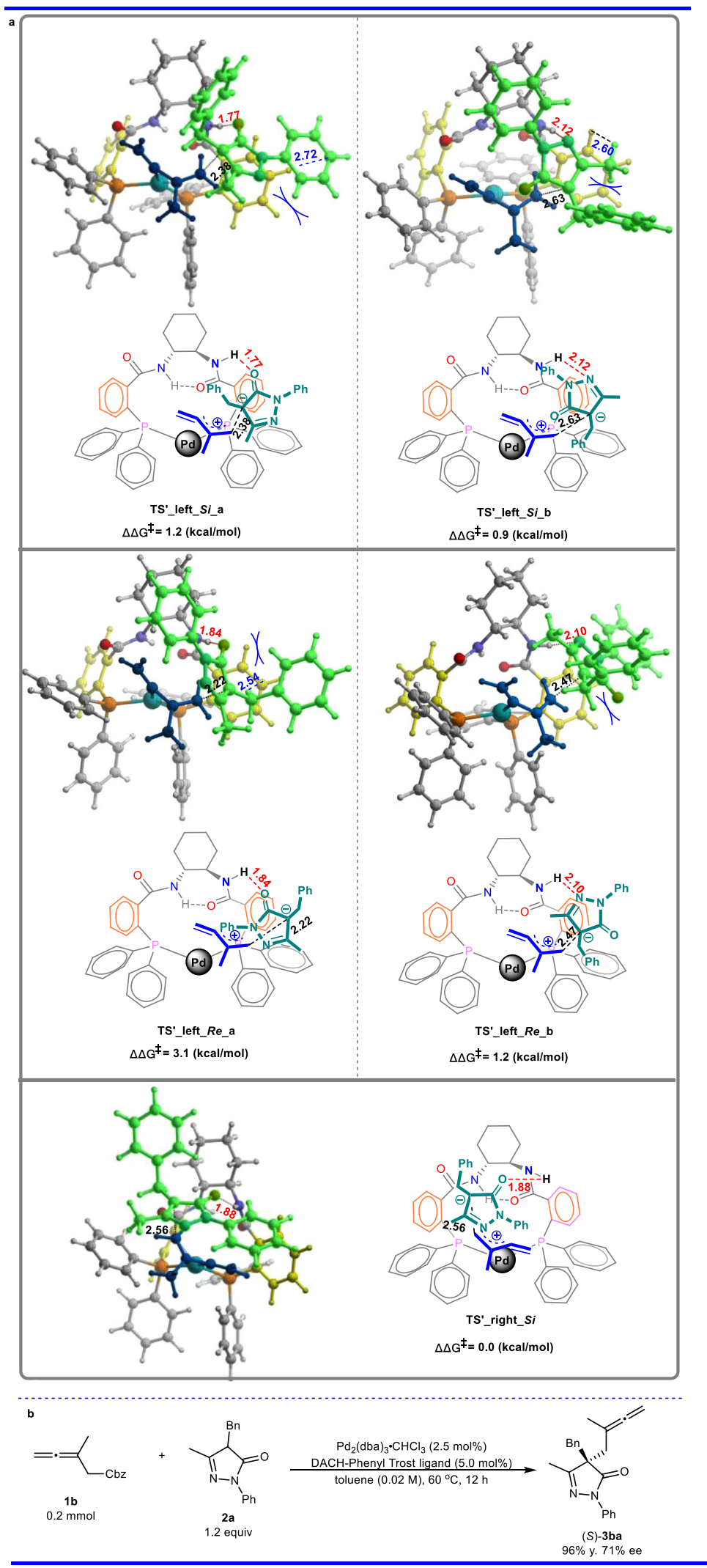

Fig. 7 DFT calculations for the DACH-Phenyl-Trost-ligated palladium catalyst. a DFT-optimized structures and relative energies of ee determining C-C bond formation transition states for the reaction of $\mathbf{1} \mathbf{b}$ with $\mathbf{2 a}$ catalyzed by the DACH-Phenyl-Trost-ligated palladium catalyst. Hydrogen-bonding interactions are shown as red dash lines; selected bond lengths $(\AA)$ are listed. $\mathbf{b}$ The reaction of $\mathbf{1 b}$ and $\mathbf{2 a}$ with DACH-Phenyl-Trost ligand. Cbz benzyloxycarbonyl, DACH $(1 R, 2 R)$-1,2-diaminocyclohexane, y. NMR yield. 
synthetically useful functionalities were tolerated under the catalysis of Pd/DACH-ZYC-Phos-C1. A rationale has been provided based on the X-ray diffraction studies of Pd(II)-DACH-ZYCPhos-C1 complex and DFT calculations. In addition, these types of stretchable chiral pockets may also provide flexiblity and show great potential applications in catalytic enantioselective allylation, allenylation, and other reactions. Such studies are being actively pursued in our laboratory with very promising results and will be reported in due courses.

\section{Methods}

General procedure for the catalytic enantioselective allenylation of pyrazol-5ones. To a flame-dried Schlenk flask were added $\mathrm{Pd}_{2}(\mathrm{dba})_{3} \cdot \mathrm{CHCl}_{3}(12.9 \mathrm{mg}$, $0.0125 \mathrm{mmol}),(R, R)$-DACH-ZYC-Phos-C1 $(14.3 \mathrm{mg}, 0.025 \mathrm{mmol})$, toluene (5 $\mathrm{mL})$, 1a (131.5 mg, $0.5 \mathrm{mmol}) /$ toluene $(11.7 \mathrm{~mL})$, and $2 \mathrm{a}(158.7 \mathrm{mg}, 0.6 \mathrm{mmol}) /$ toluene $(8.3 \mathrm{~mL})$ sequentially under nitrogen atmosphere at room temperature. The flask was put into a pre-heated oil bath and the reaction was complete after being stirred at $60^{\circ} \mathrm{C}$ for $12 \mathrm{~h}$ as monitored by TLC (eluent: petroleum ether/ethyl acetate $=20 / 1)$. The resulting mixture was filtrated through a short column of silica gel eluted with ethyl acetate $(15 \mathrm{~mL} \times 3)$. After evaporation, the crude residue was purified by chromatography on silica gel (eluent: petroleum ether $\left(60-90^{\circ} \mathrm{C}\right) /$ ethyl acetate $=60 / 1)$ to afford a pure part of $(S)$-3aa and the impure part was further purified by chromatography on silica gel (eluent: petroleum ether $\left(60-90^{\circ} \mathrm{C}\right) /$ ethyl acetate $=40 / 1)$. Two-round chromatography afforded $(S)$-3aa $(179.5 \mathrm{mg}, 96 \%)$ as a liquid: $95 \%$ ee (HPLC condition: Chiralcel IA column, $n$-hexane $/ i-\mathrm{PrOH}=90 / 10$, $1.0 \mathrm{~mL} / \mathrm{min}, \lambda=254 \mathrm{~nm}, t_{\mathrm{R}}($ major $)=5.7 \mathrm{~min}, t_{\mathrm{R}}($ minor $\left.)=8.9 \mathrm{~min}\right) ;[\alpha]_{\mathrm{D}}{ }^{20}=$ $-8.2\left(c=1.25, \mathrm{CHCl}_{3}\right) ;{ }^{1} \mathrm{H}$ NMR $\left(300 \mathrm{MHz}, \mathrm{CDCl}_{3}\right) \delta 7.55(d, J=8.1 \mathrm{~Hz}, 2 \mathrm{H}$, ArH), $7.30(t, J=7.8 \mathrm{~Hz}, 2 \mathrm{H}, \mathrm{ArH}), 7.22-7.02(\mathrm{~m}, 6 \mathrm{H}, \mathrm{ArH}), 4.64-4.49(\mathrm{~m}, 2$ $\left.\mathrm{H},=\mathrm{CH}_{2}\right), 3.18\left(d, J=13.2 \mathrm{~Hz}, 1 \mathrm{H}\right.$, one proton of $\left.\mathrm{CH}_{2}\right), 2.89(d, J=13.5 \mathrm{~Hz}, 1 \mathrm{H}$, one proton of $\left.\mathrm{CH}_{2}\right), 2.69\left(\mathrm{dt}, J_{1}=15.3 \mathrm{~Hz}, J_{2}=3.3 \mathrm{~Hz}, 1 \mathrm{H}\right.$, one proton of $\left.\mathrm{CH}_{2}\right)$, $2.39\left(d, J=15.0 \mathrm{~Hz}, 1 \mathrm{H}\right.$, one proton of $\left.\mathrm{CH}_{2}\right), 2.14\left(\mathrm{~s}, 3 \mathrm{H}, \mathrm{CH}_{3}\right), 1.93-1.80(\mathrm{~m}, 2$ $\left.\mathrm{H}, \mathrm{CH}_{2}\right), 1.43-1.17\left(\mathrm{~m}, 4 \mathrm{H}, \mathrm{CH}_{2} \times 2\right), 0.83\left(t, J=7.1 \mathrm{~Hz}, 3 \mathrm{H}, \mathrm{CH}_{3}\right) ;{ }^{13} \mathrm{C}$ NMR $(75$ $\left.\mathrm{MHz}_{1} \mathrm{CDCl}_{3}\right) \delta 205.3,174.6,161.4,137.6,134.1,129.1,128.5,128.1,127.2,124.8$, $119.3,98.3,77.7,60.1,42.8,36.1,32.3,29.4,22.1,14.7,13.8$; IR (neat) $v\left(\mathrm{~cm}^{-1}\right)$ 3063, 3031, 2956, 2927, 2859, 1954, 1712, 1597, 1500, 1455, 1440, 1402, 1366, 1123 ; MS (EI): $m / z$ (\%) $372\left([\mathrm{M}]^{+}, 31.27\right), 186(100)$; HRMS calcd. for $\mathrm{C}_{25} \mathrm{H}_{28} \mathrm{~N}_{2} \mathrm{O}[\mathrm{M}]^{+}$: 372.2202; Found: 372.2202 .

\section{Data availability}

All data that support the findings of this study are available in the online version of this paper in the accompanying Supplementary Information (including experimental procedures, compound characterization data, and spectra). The X-ray crystallographic coordinates for structures of (S)-3ak, Pd(II)-DACH-ZYC-Phos-C1 complex and Pd(II)$\mathrm{DACH}-\mathrm{Ph}$ nyl Trost ligand complex reported in this article have been deposited at the Cambridge Crystallographic Data Centre (CCDC) under deposition numbers CCDC 1971578 ((S)-3ak), 2023084 (Pd(II)-DACH-ZYC-Phos-C1 complex) and 2031404 (Pd (II)-DACH-Phenyl Trost ligand complex). These data can be obtained free of charge from http://www.ccdc.cam.ac.uk/data_request/cif.

Received: 7 October 2020; Accepted: 9 March 2021;

Published online: 23 April 2021

\section{References}

1. Varvounis, G. Advances in Heterocyclic Chemistry (ed. Katritzky, A. R.) Ch. 2 (Elsevier Inc., 2009).

2. Pan, L. C. et al. Preclinical pharmacology of CP-424,391, an orally active pyrazolinone-piperidine growth hormone secretagogue. Endocrine 14, 121-132 (2001).

3. Carpino, P. A. et al. Pyrazolinone-piperidine dipeptide Growth Hormone Secretagogues (GHSs): discovery of capromorelin. Bioorg. Med. Chem. 11, 581-590 (2003).

4. Chumakova, L. et al. Compounds Useful as Modulators of TRPM8. US0376136 (2015).

5. Zhang, Y. et al. Divergent cascade construction of skeletally diverse "Privileged" pyrazole-derived molecular architectures. Eur. J. Org. Chem. 2030-2037 (2015).

6. $\mathrm{Wu}, \mathrm{S}$. et al. Novel spiropyrazolone antitumor scaffold with potent activity: design, synthesis and structure-activity relationship. Eur. J. Med. Chem. 115, 141-147 (2016).

7. Chauhan, P., Mahajan, S. \& Enders, D. Asymmetric synthesis of pyrazoles and pyrazolones employing the reactivity of pyrazolin-5-one derivatives. Chem. Commun. 51, 12890-12907 (2015).
8. Scriven, E. F. V. \& Ramsden, C. A. Advances in Heterocyclic Chemistry Vol. 126 (Elsevier Inc., 2018)

9. Tao, Z.-L., Zhang, W.-Q., Chen, D.-F., Adele, A. \& Gong, L.-Z. Pd-catalyzed asymmetric allylic alkylation of pyrazol-5-ones with allylic alcohols: the role of the chiral phosphoric acid in $\mathrm{C}-\mathrm{O}$ bond cleavage and stereocontrol. J. Am. Chem. Soc. 135, 9255-9258 (2013).

10. Lin, H.-C. et al. Highly enantioselective allylic C-H alkylation of terminal olefins with pyrazol-5-ones enabled by cooperative catalysis of palladium complex and bronsted acid. J. Am. Chem. Soc. 138, 14354-14361 (2016).

11. Zhou, H. et al. From palladium to bronsted acid catalysis: highly enantioselective regiodivergent addition of alkoxyallenes to pyrazolones. Angew. Chem. Int. Ed. 56, 1077-1081 (2017).

12. Yang, K. et al. Asymmetric addition of pyrazolones to allenamides catalyzed by a chiral phosphoric acid. Eur. J. Org. Chem. 6469-6473 (2018).

13. Han, X. et al. Asymmetric synthesis of spiropyrazolones through phosphinecatalyzed [4+1] annulation. Angew. Chem. Int. Ed. 53, 5643-5647 (2014).

14. Li, L., Luo, P., Deng, Y. \& Shao, Z. Regioselectivity switch in palladiumcatalyzed allenylic cycloadditions of allenic esters: [4+1] or [4+3] cycloaddition/cross-coupling. Angew. Chem. Int. Ed. 58, 4710-4713 (2019).

15. Li, J.-H., Cui, Z.-H. \& Du, D.-M. Diastereo- and enantioselective construction of cyclohexanone-fused spirospyrazolones containing four consecutive stereocenters through asymmetric sequential reactions. Org. Chem. Front. 3, 1087-1090 (2016).

16. Phelan, J. P. \& Ellman, J. A. Catalytic enantioselective addition of pyrazol-5ones to trisubstituted nitroalkenes with an $\mathrm{N}$-sulfinylurea organocatalyst. $A d v$. Synth. Catal. 358, 1713-1718 (2016).

17. Hack, D. et al. Asymmetric synthesis of spiropyrazolones by sequential organo- and silver catalysis. Angew. Chem. Int. Ed. 55, 1797-1800 (2016).

18. Sharma, V., Kaur, J. \& Chimni, S. S. Chiral squaramide catalyzed enantioselective 1,6-Michael addition of pyrazolin-5-ones to styrylisox-azole derivatives. Eur. J. Org. Chem. 3489-3495 (2018).

19. Chauhan, P. et al. Asymmetric synthesis of amino-bis-pyrazolone derivatives via an organocatalytic Mannich reaction. J. Org. Chem. 82, 7050-7058 (2017)

20. Kaya, U. et al. Squaramide-catalyzed asymmetric aza-Friedel-Crafts/N,Oacetalization domino reactions between 2-naphthols and pyrazolinone ketimines. Angew. Chem. Int. Ed. 56, 15358-15362 (2017).

21. Yang, Z.-T., Yang, W.-L., Chen, L., Sun, H. \& Deng, W.-P. Organocatalytic enantioselective aza-Friedel-Crafts reactions of pyrazolinone ketimines with hydroxyindoles and electron-rich phenols. Adv. Synth. Catal. 360, 2049-2054 (2018).

22. Vetica, F., Chauhan, P., Mahajan, S., Raabe, G. \& Enders, D. Asymmetric organocatalytic Friedel-Crafts hydroxyalkylation of indoles using electrophilic pyrazole-4,5-diones. Synthesis 50, 1039-1046 (2018).

23. Amr, F. I., Vila, C., Blay, G., Muñoz, M. C. \& Pedro, J. R. Organocatalytic enantioselective alkylation of pyrazol-3-ones with isatin-derived ketimines: stereocontrolled construction of vicinal tetrasubstituted stereocenters. $A d v$. Synth. Catal. 358, 1583-1588 (2016).

24. Wang, L. et al. Asymmetric, three-component, one-pot synthesis of spiropyrazolones and 2,5-chromenediones from aldol condensation/ $\mathrm{NHC}$ catalyzed annulation reactions. Chem. Eur. J. 22, 5123-5127 (2016).

25. Li, S.-W., Wan, Q. \& Kang, Q. Chiral-at-metal Rh(III) complex-catalyzed Michael addition of pyrazolones with $\alpha, \beta$-unsaturated 2-acyl imidazoles. Org. Lett. 20, 1312-1315 (2018).

26. Bao, X. et al. Asymmetric construction of a multi-pharmacophore-containing dispirotriheterocyclic scaffold and identification of a human carboxylesterase 1 inhibitor. Org. Lett. 20, 3394-3398 (2018).

27. Zhou, J., Huang, W.-J. \& Jiang, G.-F. Synthesis of chiral pyrazolone and spiropyrazolone derivatives through squaramide-catalyzed reaction of pyrazolin-5-ones with o-quinone methides. Org. Lett. 20, 1158-1161 (2018).

28. Hoffmann-Röder, A. \& Krause, N. Synthesis and properties of allenic natural products and pharmaceuticals. Angew. Chem. Int. Ed. 43, 1196-1216 (2004).

29. Xu, D., Drahl, M. A. \& Williams, L. J. Toward an integrated route to the vernonia allenes and related sesquiterpenoids.Beilstein J. Org. Chem. 7, 937-943 (2011).

30. Eglen, R. M. \& Whiting, R. L. Characterization of the prostanoid receptor profile of enprostil and isomers in smooth muscle and platelets in vitro. $\mathrm{Br}$. J. Pharmacol. 98, 1335-1343 (1989).

31. Ma, S. Some typical advances in the synthetic applications of allenes. Chem. Rev. 105, 2829-2871 (2005).

32. Krause, N. \& Winter, C. Gold-catalyzed nucleophilic cyclization of functionalized allenes: a powerful access to carbo- and heterocycles. Chem. Rev. 111, 1994-2009 (2011).

33. $\mathrm{Yu}, \mathrm{S}$. \& Ma, S. Allenes in catalytic asymmetric synthesis and natural product syntheses. Angew. Chem. Int. Ed. 51, 3074-3112 (2012).

34. Alcaide, B., Almendros, P. \& Aragoncillo, C. Cyclization reactions of bis (allenes) for the synthesis of polycarbo(hetero)cycles. Chem. Soc. Rev. 43, 3106-3135 (2014). 
35. Muñoz, M. Silver and platinum-catalysed addition of $\mathrm{O}-\mathrm{H}$ and $\mathrm{N}-\mathrm{H}$ bonds to allenes. Chem. Soc. Rev. 43, 3164-3183 (2014).

36. Lledó, A., Pla-Quintana, A. \& Roglans, A. Allenes, versatile unsaturated motifs in transitionmetal-catalysed $[2+2+2]$ cycloaddition reactions. Chem. Soc. Rev. 45, 2010-2023 (2016).

37. Liu, L., Ward, R. M. \& Schomaker, J. M. Mechanistic aspects and synthetic applications of radical additions to allenes. Chem. Rev. 119, 12422-12490 (2019).

38. Liu, X., Lin, L. \& Feng, X. Chiral $N, N$-dioxides: new ligands and organocatalysts for catalytic asymmetric reactions. Acc. Chem. Res. 44, 574-587 (2011).

39. Liu, X., Zheng, H., Xia, Y., Lin, L. \& Feng, X. Asymmetric cycloaddition and cyclization reactions catalyzed by chiral $N, N^{\prime}$-dioxide-metal complexes. Acc. Chem. Res. 50, 2621-2631 (2017).

40. Liu, X., Lin, L. \& Feng, X. Chiral $N, N^{\prime}$-dioxide ligands: synthesis, coordination chemistry and asymmetric catalysis. Org. Chem. Front. 1, 298-302 (2014).

41. Liu, X., Dong, S., Lin, L. \& Feng, X. Chiral amino acids-derived catalysts and ligands. Chin. J. Chem. 36, 791-797 (2018).

42. Tsvetkov, E. N., Bondarenko, N. A., Malakhova, I. G. \& Kabachnik, M. I. A simple synthesis and some synthetic application of substituted phosphide and phosphinite anions. Synthesis 198-208 (1986).

43. Guisado-Barrios, G. et al. Cyclic decapeptide gramicidin S derivatives containing phosphines: novel ligands for asymmetric catalysis. Dalton Trans. 42, 1973-1978 (2013).

44. Trost, B. M., Vranken, D. L. V. \& Bingel, C. A modular approach for ligand design for asymmetric allylic alkylations via enantioselective palladiumcatalyzed ionizations. J. Am. Chem. Soc. 114, 9327-9343 (1992).

45. Cao, M.-Y. et al. Optically active flavaglines-inspired molecules by a palladium-catalyzed decarboxylative dearomative asymmetric allylic alkylation. J. Am. Chem. Soc. 142, 12039-12045 (2020).

46. Han, Y., Zhao, Y. \& Ma, S. Rhodium-catalyzed Pauson-Khand-type cyclization of 1,5-allene-alkynes: a chirality transfer strategy for optically active bicyclic ketones. Chem. Eur. J. 25, 9529-9533 (2019).

47. Casanova, N. et al. Palladium(II)-catalyzed annulation between orthoalkenylphenols and allenes. Key role of the metal geometry in determining the reaction outcome. ACS Catal. 6, 3349-3353 (2016).

48. Trost, B. M., Machacek, M. R. \& Aponick, A. Predicting the stereochemistry of Diphenylphosphino Benzoic Acid (DPPBA)-based palladium-catalyzed asymmetric allylic alkylation reactions: a working model. Acc. Chem. Res. 39, 747-760 (2006).

49. Ogasawara, M. et al. Synthesis, structure, and reactivity of (1,2,3- $\eta^{3}$-Butadien3-yl)palladium complexes. Organometallics 26, 5025-5029 (2007).

50. Benyunes, S. A. et al. Reactions of co-ordinated ligands. J. Chem. Soc. Dalton Trans. 3785-3793 (1993).

51. Swanson, R. A., Patrick, B. O., Ferguson, M. J. \& Daley, C. J. A. Tetracoordinate diamidato-bis(phosphanyl) metal systems: synthesis, characterization, and electrochemical analysis of palladium(II) complexes. Inorg. Chim. Acta 360, 2455-2463 (2007).

52. Endo and exo were labeled according to Helmchen's conventional notation specifying the orientation of its allyl fragment with respect to the metal-center plane.

53. Brown, I. D. \& Altermatt, D. Bond-valence parameters obtained from a systematic analysis of the inorganic crystal structure database. Acta Crystallogr. Sect. B 41, 244-247 (1985).

54. Emamian, S., Lu, T., Kruse, H. \& Emamian, H. Exploring nature and predicting strength of hydrogen bonds: a correlation analysis between atomsin-molecules descriptors, binding energies, and energy components of symmetry-adapted perturbation theory. J. Comput. Chem. 40, 2868-2881 (2019).

55. Lu, T. \& Chen, F. Multiwfn: a multifunctional wavefunction analyzer. $J$. Comput. Chem. 33, 580-592 (2012).

56. Lu, T. Multiwfn, version 3.5 .

57. Humphrey, W., Dalke, A. \& Schulten, K. VMD: visual molecular dynamics. J. Mol. Graph. 14, 33-38 (1996).

\section{Acknowledgements}

Financial support from the National Natural Science Foundation of China (Grant Nos. 21690063 and 21988101) is greatly appreciated. We thank Haibo Xu in this group for reproducing the preparation of (S)-3ba, (S)-3af, and (S)-3ar. Shengming Ma is a Qiu Shi Adjunct Professor at Zhejiang University.

\section{Author contributions}

S.M. directed the research and developed the concept of the reaction with Y. Z., who also performed the experiments and prepared the Supplementary Information. X.Z. performed the computational studies. Y.Z., X.Z., and S.M. wrote the manuscript and checked the experimental data.

\section{Competing interests}

The authors declare no competing interests.

\section{Additional information}

Supplementary information The online version contains supplementary material available at https://doi.org/10.1038/s41467-021-22498-1.

Correspondence and requests for materials should be addressed to X.Z. or S.M.

Peer review information Nature Communications thanks Gaoxi Jiang and the other anonymous reviewers for their contribution to the peer review of this work. Peer reviewer reports are available.

Reprints and permission information is available at http://www.nature.com/reprints

Publisher's note Springer Nature remains neutral with regard to jurisdictional claims in published maps and institutional affiliations.

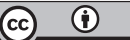

Open Access This article is licensed under a Creative Commons Attribution 4.0 International License, which permits use, sharing, adaptation, distribution and reproduction in any medium or format, as long as you give appropriate credit to the original author(s) and the source, provide a link to the Creative Commons license, and indicate if changes were made. The images or other third party material in this article are included in the article's Creative Commons license, unless indicated otherwise in a credit line to the material. If material is not included in the article's Creative Commons license and your intended use is not permitted by statutory regulation or exceeds the permitted use, you will need to obtain permission directly from the copyright holder. To view a copy of this license, visit http://creativecommons.org/ licenses/by/4.0/.

(c) The Author(s) 2021 